\title{
PENGARUH PEMBERIAN SARI KEDELAI TERHADAP PENURUNAN TEKANAN DARAH PADA PENDERITA HIPERTENSI DI RW O1 DESA SUKODONO KECAMATAN PUJER BONDOWOSO
}

\author{
Oleh: \\ Eka Suryaning Tyas, Lutfi Mukhofi \\ STIKes Bhakti Al Qodiri Jember, tyaseka511@gmail.com
}

\begin{abstract}
ABSTRAK
Penyakit darah tinggi yang berkembang saat ini belum tentu di ketahui oleh penderitanya karena kadang-kadang penyakit darah tinggi tidak memunculkan gejala-gejala atau keluhan-keluhan sehingga di sebut the silent killer. Adaput pengobatan hipertensi secara farmakologis dapat menimbulkan efek samping pada penggunanya, sehingga menyebabkan masyarakat memilih buah dan sayuran sebagai alternatif pengobatan hipertensi, salah satunya dengan terapi sari kedelai. Sari kedelai merupakan minuman yang bergizi tinggi,terutama dengan kandungan proteinnya. Selain itu sari kedelai juga mengandung lemak, karbohidrat, kalsium, mineral magnesium, phospor, zat besi, provitamin A, vitamin B komplek dan air. Tujuan penelitian ini adalah untuk menganalisis pengaruh pemberian sari kedelai terhadap penurunan tekanan darah pada penderita hipertensi di RW 01 Desa Sukodono kecamatan Pujer Bondowoso.
\end{abstract}

Kata Kunci : Sari Kedelai, Tekanan Darah, Hipertensi

\section{ABSTRACT}

High blood pressure that develops at this time is not necessarily known by the sufferer as it sometimes does not bring high blood pressure symptoms or complaints that are called the silent killer. The pharmacologic treatment of hypertension can cause side effects on its users, thus causing people to choose fruits and vegetables as an alternativetreatment of hypertension, one with soymilk therapy. Soymilk is a highly nutritious beverage, especially sinca the protein content. In addition soymilk also contains fat, carbohydrates, calcium,minerals magnesium, phosphorus, iron, provitamin A, vitamin B complex and water. The purpose of this study was to analyze the effect of soymilk to decrease blood pressure for people of hypetension in RW 01 Sukodono village districts Pujer Bondowoso.

Keywords : Soybean, Blood Pressure, Hypertension 


\section{PENDAHULUAN}

\section{Latar Belakang}

Hipertensi adalah merupakan tekanan darah di atas skala normal (120/80 $\mathrm{mmHg}$ ). Hipertensi juga dikatakan sebagai suatu keadaan di mana tekanan sistolik lebih dari $140 \mathrm{mmHg}$ dan/atau tekanan diastoli lebih dari $90 \mathrm{mmHg}$ (Damayanti, 2009).

Hipertensi dapat menyebabkan meningkatnya risiko terhadap serangan jantung (infark miokard akut)., gagal jantung, gagal ginjal, kerusakan mata dan stroke. Komplikas-komplikasi hipertensi ini bisa terjadi karena kerusakan pada organ-organ ini akibat dari tekanan darah tinggi kronis (Nurheti, 2011).

\section{Hasil Riset Kesehatan Dasar} (Riskesdas) 2007 menunjukkan sebagian besar kasus hipertensi di masyarakat belum teratasi. Hal ini terlihat dari hasil pengukuran tekananan darah pada usia 18 tahun ke atas ditemukan privalensi hipertensi di indonesi $31,7 \%$, di mana hanya $7,2 \%$ penduduk yang sudah mengetahui mempunyai penderita hipertensi da hanya $0,4 \%$ kasus yng minum obat anti hipertensi (Depkes, 2012)

Dari hasil studi pendahuluan yang berupa wawancara dan observasi pada tanggal 01 November 2013 Di Desa Sukodono terdapat 3.150 jiwa, yang menderita hiprtensi terdapat 115, sedangkan di RW 01 desa Sukodono

terdapat 40 orang yang menderita hiprtensi dengan rincian 17 laki-laki dan 23 perempuan.

Penatalaksanaan non medikamentosa dilakukan dengan mengubah gaya hidup, mencakup pola diet sehat, latihan fifisk secara teratur, menghindari stres dan berhenti merokok. Penatalaksanaan non medikamentosa tidak selalu dapat menurunkan tekanan darah, sehingga diperlukan penatalaksanaan medikamentosa dengan menggunakan obat. Masing-masing obat mempunyai efek samping yang berbeda-beda. Adanya efek samping obat-obat kimia tersebut menyababkan masyarakat memilih buah dan sayuran yang ada sebagai alternatif pengobatan hipertensi (Glycine max, Legumentosa) (Nur Kholish, 2011).

Penelitian Jery L. Nadler (2010) dari City of Hope Medical Center California, menyebutkan magnesium yang terdapat dalam sari kedelai mampu menghambat pelepasan tromboksari, yaitu suatu zat yang membuat trombosit (keping dara) menjadi lebih lengket dan mudah membentuk gumpalan, sehingga mampu mencegah naiknya tekanan darah sekaligus mencegah stroke dan gangguan jantung.

Penelitian di Tulane University School of Publik Health dan Tropical Medivine di New Orleans, telah 
mengevaluasi efek dari protein dan karbohidrat dalam susu kedelai pada 325 orang dewasa yang menderita hipertensi dengan tekanan darah yang mengkisar 120-125 mmHg dan tekanan darah diastolik 80-95 $\mathrm{mmHg}$, protein kedelai di anggap dapat menurunkan tekanan darah sistolik sebesar $10 \mathrm{mmHg}$. Berdasarkan latar belakang di atas penulis tertarik untuk meneliti pengaruh pemberian sari kedelai terhadap penurunan tekanan darah pada penderita hipertensi di RW 01 Desa Sukodono kecamatan Pujer Bondowoso.

\section{METODE PENELITIAN}

Rencana atau desain penelitian adalah sesuatu yang sangat penting dalam penelitian, yang memungkinkan kemaksimalan kontrol beberapa faktor yang bisa mempengaruhi akurasi suatu hasil. Penelitian ini menggunakan bentuk rancangan pra eksperimental dengan rancangan one group pre test-post test design, yaitu mengungkapkan hubungan sebab akibat dengan cara melibatkan satu kelompok subjek (Nursalam, 2013)

Rancangan ini tidak ada kelompok pembanding (kontrol), tetapi paling tidak sudah di lakukan observasi pertama (pretest) yang memungkinkan peneliti dapat menguji perubahan-perubahan yang terjadi setelah adanya eksperimen.

\section{HASIL PENELITIAN}

Pengaruh pemberian sari kedelai terhadap penurunan tekanan darah pada penderita hipertensi RW 1 Desa Sukodono Pujer Bondowoso. Data yang di peroleh akan di sajikan dalam bentuk diagram pie, tebel, grafik dan narasi. Penyajian hasil di bagi menjadi dua yaitu data umum dan data khusus. Data umum meliputi umur dan jenis kelamin, sedangkan data khusus meliputi data pretest dan prostest terhadap responden serta analisa data.

\section{Data Umum}

Data umum meliputi karakteristik responden berdasarkan umur, jenis kelamin, dan pendidikan

1. Karakteristik responden

Berdasarkan umur

Tabel 5.1 Umur Responden pengaruh pemberian sari kedelai terhadap penurunan tekanan darah pada penderita hipertensi di RW 01 Desa Sukodono Kecamatan Pujer Bondowoso.

\begin{tabular}{|l|l|l|}
\hline $\begin{array}{l}\text { Umur } \\
\text { (Tahun) }\end{array}$ & $\begin{array}{l}\text { Frekuensi } \\
(\mathbf{F})\end{array}$ & $\begin{array}{l}\text { Prasentase } \\
(\boldsymbol{\%})\end{array}$ \\
\hline $30-45$ & 9 & 45 \\
\hline $46-59$ & 8 & 40 \\
\hline$>60$ & 3 & 15 \\
\hline JUMLAH & $\mathbf{2 0}$ & $\mathbf{1 0 0}$ \\
\hline
\end{tabular}

Sumber : Data Primer Penelitian, 2014 
Berdasarkan tabel 5.1 dapat diketahui bahwa responden yang memiliki umur 30-45 tahun yaitu sejumlah 9 responden $(45 \%)$, responden dengan umur 46-59 tahun sejumlah 8 responden (40\%), dan responden yang berumur $>60$ tahun sejumlah 3 responden (15\%)

2. Karakteristik Responden

Berdasarkan jenis kelamin

Gambar 5.1 Distribusi Frekuensi

Responden menurut jenis kelamin Responden pengaruh pemberian sari kedelai terhadap penurunan tekanan darah tinggi penderita hipertensi RWI Desa Sukodono Pujer Bondowoso.

3. Karakteristik Responden

Berdasarkan Pendidikan

Gambar 5.1 Distribusi Frekuensi Responden menurut pendidikan responden pengaruh sari kedelai terhadap penurunan tekanan darah pada penderita hipertensi di RW Desa Sukodono Pujer Bondowoso.

\section{Data Khusus}

Data Khusus meliputi Data Nilai Tekanan Darah Pretest, Data Nilai Tekanan Darah Postest, dan Data Tentang Tekanan Darah

1. Data Nilai Tekanan Darah Pretest

Dapat di ketahui bahwa sebelum dilakukan pemberian sari kedelai, nilai mean sistol 153.50 dan diastole 96.00, nilai median sistol 150.00 dan diastole 95.00, nilai modus sistol 150 dan diastole 90 dengan Std. Deviation sistol 9.747 dan diastole 9.403 dan nilai minimal sistol 140 dan diastole 80 dan maksimalnya sistol 170 dan diastole 110.

2. Data Nilai Tekanan Darah Postest

Dapat di ketahui bahwa setelah di lakukan pemberian sari kedelai, nilai mean nya adalah sistol 142.00 dan diastole 86.25, nilai median sistol 140.00 dan diastole 85.00 , nilai modus sistole 130 dan diastole 80 dengan Std. Deviation sistl 9.652 dan diastole 7.587 dan nilai minimal sistol 130 dan nilai maksimalnya sistol 160 dan diastole 100

\section{Data Tentang Tekanan Darah}

Pretest dan Postest

Dengan menggunakan penghitungan manual di ketahui bahwa sebelum dilakukan pemberian sari kedelai nilai mean 153.50 , median 150,00 modus 150, Std. Deviation 9,747 dan minimal 140 dengan nilai meannya 170 sedangkan setelah dilakukan pemberian sari kedelai ini meannya sistol 142.00, median 14.00 , modus 130, Std deviation 9.652 dan nilai minimal 130 dan nilai maksimalnya 160 dengan jumlah mean 295.50, median 164.00, modus 280, Std devation 19.399, nilai manimal 270 dan nilai maksimal 330. Yang artinya ada 
pengaruh pemberian sari kedelai terhadap penurunan tekanan darah di RW 01 desa Sukodono Kecamatan Pujer Bondowoso.

\section{Analisa Data}

Berdasarkan hasil uji statistic menunjukan bahwa terdapat perubahan nilai mean yang signifikan pada pretest dan posttest pemberian sari kedelai, dimana mean pretest adalah 153.50 dan setelah dilakukan pemberian sari kedelai menjadi 142.00 .

\section{PEMBAHASAN}

Tekanan darah pada penderita hipertensi di RW 1 desa Sukodono

1. Sebelum di lakukan pemberian sari kedelai.

Berdasarkan penelitian yang di lakukan pada bulan maret-mei 2014 di RW 1 desa Sukodono Pujer Bondowoso, sebelum dlakukan pemberian sari kedelai pada penderita hipertensi yang mengalami kenaikan tekanan darah di dapatkan bahwa nilai meannya adalah 153.50 dan diastol 96.00 dengan nilai meannya sistole 150.00 dan diastol 95.00 nilai modus yaitu sistol 150 dan diastol 90

Hasil observasi peneliti pada responden di dapatkan bahwa tekanan darah pasa penderita hipertensi berbeda-beda. Hal ini di pengaruhi oleh aktivitas, umur, obesitas, kolesterol, stress, kurang aktibitas fisik dan penyakit lainnya seperti gagal jantung, gagal ginjal, arterosklorosi dan sebgainnya. Dari semua responden dan yang di dapatkan ketika responden mengalami kenaikan tekanan darah kebanyakan responden tidak mengetahui apa yang di deritanya karena sebagian besar responden pendidikannya masih kuang sehingga penatalaksanannya terhadap penyakit kurang tepat.

2. Setalah dilakukan pemberian sari kedelai.

Hasil penelitian setelah di lakukan pemberian sari kedelai menunjukan terjadinya penurunan tekanan darah, dimana nilai meannya adalah sistol 142,00 dan diastol 86.00 dengan nilai median sistol 140.00 dan diastole 85.00 dan nilai modusnya sistol 130 dan diastol 80. Hal ini dapat di ketahui ketika pada saat sebelum di lakukan pemberian sari kedelai responden mengalami kenaikan tekanan darah, sedangkan setalah di lakukan pemberian sari kedelai responden mengalami penurunan tekanan darah.

Hal ini sesuai dengan Penelitian Jery L. Nadler (2010) dari City of Hope Medical-California, menyebutkan magnesium yang terdapat dalam sari 
kedelai mampu menghambat pelepasan tromboksan, yaitu suatu zat yang membuat trombosit (kepingen darah) menjadi lebih lengket dan mudah mebentuk gumpalan, sehingga mampu mencegah naiknya tekanan darah sekaligus mencegah stroke dan gangguan jantung.

Penelitian di Tulane Univercity School of Public Health dan Tropical Medicine di New Orleans, telah mengevaluasi efek dari protein dan karbohidrat dalam susu kedelai pada 352 orang dewasa yang menderita hipertensi, baik pra-hipertensi maupun hipertensi tahap awal, dengan tekanan darah berkisar 120-159 $\mathrm{mmHg}$ dan tekanan darah diastolik $80-95 \mathrm{mmHg}$. Setiap relawan menerima $450 \mathrm{ml}$ suplemen susu kedelai setiap hari selama empat minggu. Dalam studi tersebut menemukan bahwa, protein kedelai dianggap dapat menurunkan tekanan darah sistolik sebesar 10 mmHg. Protein dari susu kedelai ini mungkin merupakan komponen penting untuk mencegah dan pengobatan terhadap hipertensi.

3. Pengaruh pemberian sari kedelai terhadap penurunan tekanan darah

Hasil penelitian sebelum dan setelah dilakukan pemberian sari kedelai terhadap penurunan tekanan darah. Mean tekanan darah sebelum di lakukan pemberian sari kedelai menjadi sistol 153,50 dan diastol 96.00 dan setelah di lakukan pemberian sari kedelai menjadi sistol 142.00 dan diastole 95.00. hal ini isebabkan karena sari kedelai mengandung magnesium yang dapat menghambat pelepasan trombosan, yaitu suatu zat yang membuat trombosit (kepingan darah) menjadi lebih lengket dan mudah membentuk gumpalan, sehingga mampu mencegah naiknya tekanan darah sekaligus mencegah stroke dan gangguan jantung.

Selain itu dari hasil output SPSS diketahui bahwa harga signifikan $p$ value di mana nilai $p=0.000$ oleh karen $p$ value $(0.000) \leq 0.05$, maka Ho di tolak artinya ada perbedaan rata-rata antara nilai sebelumnya dilakukan pemberian sari kedelai dan setelai di lakukan pemberian sari kedelai sehingga dapat dinyatakan erdapat pengaruh pemberian sari kedelai terhadap penurunan tekanan darah pada penderita hipertensi di RW 1 desa Sukodono Pujer Bondowoso yang berarti H1 Diterima

Sari kedelai merupakan minuman yang bergizi tinggi, terutama karena kandungan proyeinnya. Selain itu sari kedelai juga mengandung lemak, karbohidrat, kalsium, mineral 
magnesium, phosphor, zat besi, provitamin A, vitamin B komplek (kecuali B12) dan air (Salim, 2012)

Menurut Salim (2012), komposisi sari kedelai hampir sama dengan susu sapi. Sari ini baik dikonsumsi bagi yang alergi susu sapi. Dibandingkan susu sapi, komposisi asm amino dalam protein sari kedelai kekurangan jumlah asam amino metionin dan sistein. Tetapi, karena kandungan asam amino lisin cukup tinggi, maka sari kedelai dapat meningkatkan nilai gizi protein dani nasi dan makanan sereal lainnya.

\section{KESIMPULAN DAN SARAN}

\section{Kesimpulan}

Berdasarkan tujuan khusus tentang pengaruh pemberian sari kedelai terhadap penurunan tekanan darah pada penderita di RW 1 Desa Sukodono Pujer Bondowoso dapat di simpulkan bahwa :

1. Tekanan darah sebelum dilakukan pemberian sari kedelai nilai meannya adalah sistol 153.50 dan diastol 96.00 dengan nilai media sistol 150.00 dan diastol 95.00 dan nilai modus yaitu sistol 150 dan distol 90

2. Tekanan setelah di lakukan pemberian sari kedelai nilai meannya adalah systole 142.00 dan distol 86.00 dengan nilai median sistol 140.00 dan diastol
85.00 dan nilai modus yaitu 130 dan diastol 80

3. Ada pengaruh pemberian sari kedelai terhadap penurunan tekanan darah pada penderita hipertensi di RW 1 Desa Sukodono Kec.Pujer Bondowoso

\section{DAFTAR PUSTAKA}

1. Alimul,A.2007. Riset Keperawatan dan Penelitian Ilmiah, Salemba Media, Jakarta

2. Amiruddin, R 2007. Hipertensi dan faktor resikonya dalam kejadian Epidemiologi.

3. Anggraeni. Yofina.2012. Super komplet pengobatan darah tinggi.Pinang merah, Yogyakarta

4. Arikunto suhami.2010. prosedur penelitian.edisi.edisi revisi 2010. Rineka.Yogyakarta

5. Damayanti.D. 2013. Sembuh total diabetes asam urat hipertensi tanpa obat. Pinang merah puplisher.Yogyakarta

6. Esalim Emil,2012. Kiat cerdas wirausaha. Aneka olahan kedelai.lily puplisher.Yogyakarta

7. Garnadi yudi,2012. Hidup nyaman dengan hipertens. PT agromedia pustaka.Jakarta

8. Gunawan Lany.2001. Hipertensi tekanan darah tinggi. Yogyakarta 
9. Herlambang.2013.Menahklukkan

hipertensi dan diabetes. Suka buka,

Jakarta selatan

10. Kuswara, S.2006. Susu kedelai tak kalah dengan susu sapi. Ebookpangan .com2006. Akses 14-2-2010

11. Lumbantobing.2008. Tekanan Darah Tinggi. FKUI. Jakarta

12. Magz.2009. kedelai menghindari tekanan darah tinggi. http://passionmagz.com /kedele menghiday-tekanan-darahtinggi/2009/08/07. Akses 14-2-2010

13. Martha.karnia.2012.Panduan cerdas mengatasi hipertensi. Araska.Yogyakarta 